\title{
抗菌薬適正使用支援における薬剤師の役割
}

\author{
村木 優一
}

\section{The Role of Pharmacists in Antimicrobial Stewardship}

\author{
Yuichi Muraki \\ Department of Clinical Pharmacoepidemiology, Kyoto Pharmaceutical University; \\ 5 Misasagi-Nakauchi-cho, Yamashina-ku, Kyoto 607-8414, Japan.
}

(Received August 17, 2018)

\begin{abstract}
Antimicrobial resistance (AMR) has been declared a global public health emergency, necessitating the involvement of the whole of society to address this increasingly serious threat. AMR causes prolonged illness, greater risk of infection spread, increased morbidity, and higher mortality rates, which result in increased expenses to the government, healthcare services, and individuals. Inappropriate use of antimicrobials has been indicated as the primary cause for the global expansion of AMR. Under these circumstances, various countries have formulated suitable national action plans to curb AMR. In Japan, the national action plan on AMR was announced in April 2016. Our previous study clarified that orally administered antimicrobials accounted for approximately $90 \%$ of total consumption: oral third-generation cephalosporins, macrolides, and fluoroquinolones accounted for approximately $77 \%$ of oral consumption. Therefore pharmacists must extend their support for the appropriate use of antimicrobials prescribed by attending physicians to not only hospitalized patients but also outpatients. "Choosing wisely," a US-based health education campaign, warns against unnecessary use of antimicrobials. Pharmacists should strive to disseminate the concept of "choosing wisely" in relation to other medicines, implement further interventions, and evaluate them. In this article, we present data on use of antimicrobials in Japan, and mention how pharmacists should be involved in enabling physicians choose antimicrobials wisely.
\end{abstract}

Key words — choosing wisely; antimicrobial stewardship; antimicrobial resistance; national action plan on antimicrobial resistance

\section{はじめに}

Choosing Wisely（賢明な選択）は，Brodyによ り各医療分野における根拠がそしいにもかかわら ず，日常的に実施されている医療行為を 5 つ挙げる 呼びかけ1)に対して American Board of Internal Medicine (ABIM) 財団が 2012 年に始めたキャン ペーンである. 現在は 70 以上の学会, 団体が 400 余りのリストを提唱し, ${ }^{2}$ 国際的な活動に発展して おり，日本においても徳田や小泉を中心に 2014 年 頃から活動が行われている. ${ }^{2-4)}$ Choosing Wisely は, 診断, 検査, 治療など様々な医療行為に対して 推奨されているが，米国の調査において 70 の学会,

京都薬科大学臨床薬剂疫学分野（ $\bar{T} 607-8414$ 京都市山 科区御陵中内町 5)

e-mail: y-muraki@mb.kyoto-phu.ac.jp.

本総説は, 日本薬学会第 138 年会シンポジウムS22 で 発表した内容を中心に記述したものである.
415 の推奨のうち，26.5\%が薬物治療に関連したも のであり，そのうち，抗菌薬 $(21.8 \%)$ が最も多く を占めていたことを報告している. ${ }^{5)}$

一方，抗菌薬耐性（antimicrobial resistance; AMR）が世界的な公衆衛生上の緊急事態として宣 言され，拡大するパンデミックに対処するため，社 会全体の行動を必要としている. AMR は疾病の長 期化，伝搬リスクの増大，罹患率・死亡率の上昇を 招き，結果的に財政的かつ社会的費用の増加も伴 う. ${ }^{6}$ AMR の拡大の背景には, 抗菌薬の不適切な 使用が指摘されていることから，世界各国で国家行 動計画が策定され，わが国においても 2016 年 4 月 に AMR 対策アクションプランが公表された. ${ }^{7)}$ Choosing Wisely において抗菌薬が多くを占める理 由には，こうした背景も大きく影響していることが 考えられる.

また，日本では平成 30 年度診療報酬改定におい 
て主治医が抗菌薬を適正に使用できるように支援す る（antimicrobial stewardship）体制を評価した診 療報酬制度も新設された。そのため, 薬剤師は，入 院患者だけでなく，外来患者を含めたすべての患 者，国民に対して抗菌薬の適正使用を支援すること が求められている。そこで本総説では，筆者がこれ までに得た日本における抗菌薬使用状況や取り巻く 現状を示し，抗菌薬における Choosing Wisely（賢 明な選択）に薬剤師がごのように係わっていくべき かについて言及したい.

\section{AMR 対策アクションプランとは}

ペニシリンが 1928 年に発見され，1940 年代に実 用化されるよりも前に大腸菌や黄色ブドウ球菌に分 解酵素（ペニシリナーゼ）が認められたように，抗 菌薬の開発と耐性菌の出現は相まっている. ${ }^{8)}$ その 後も次々と新しい抗菌薬が開発されては新たな而性 菌が出現しているものの，新たな抗菌薬開発やワク チンの普及は感染症がもはや不治の病ではないとい う認識を広めることとなった。そのため, 先進国に おける主な死因が感染症から非感染性疾患へと変化 したことが製薬の主流をシフトさせ，新たな抗菌薬 が開発されなくなっている。しかしながら，医療技 術は進歩し，手術や医療機器に関連した医療関連感 染症や移植医療やがん化学療法などに伴う易感染患 者が増加し，耐性菌の脅威はむしろ増している。さ らに，メチシリン耐性黄色ブドウ球菌（methicillinresistant Staphylococcus aureus; MRSA) や多剂耐 性緑膿菌 (multi drug resistant Pseudomonas aeruginosa；MDRP）など，多剂耐性菌による医療関連 感染症が時折アウトブレイクし，現在も医療機関に おいて大きな問題となっている.

耐性菌による感染症は国によって規模は異なるも のの，米国では年間 200 万人以上が罹患し，死亡率 も耐性菌による感染症は選択できる抗菌薬が限定さ れることから，感性菌による感染症に比べて約 2-3 倍程度高い。 $\left.{ }^{8}\right)$ また，耐性菌による感染症は入院期 間を延長させ，高額な抗菌薬の治療継続により医療 費を増大させる. $\left.{ }^{6}\right)$ さらに，感染拡大を防止するた めには，対策費用や病棟閉鎖などによる多大なる損 失も引き起こす。こうした現状において WHO は, 2015 年に加盟各国に対して 2 年以内の AMR 対策 に関する国家行動計画の策定を求めた．それを受け てわが国においても，2016 年 4 月 5 日に行われた
国際的に脅威となる感染症対策関係閣僚会議におい て「AMR 対策アクションプラン」が決定された. ${ }^{7)}$ 今回，策定された AMR 対策アクションプランは Table 1 に示すように(1)普及啓発・教育，(2)動向調 査・監視，(3)感染予防・管理，(4)抗微生物剂の適正 使用，(5)研究開発・創薬，6)国際協力といった $6 つ$ の目標から成り立っている．また，それぞれの目標 に対して背景，方針，取り組み，評価指標などが記 されており，最終的にアクションプランとしての成 果指標が示されている.

例えば，目標(2)動向調査・監視では，薬剤耐性及 び抗微生物剤の使用量を継続的に監視し，薬剂耐性 の変化や拡大の予兆を適確に把握するため, 4 つの 戦略が掲げられている。，そのうち，戦略 2.2 として 医療機関における抗微生物薬の使用量の動向の把握 が示されており，後述する筆者がこれまで行ってき た抗菌薬の使用動向調査 ${ }^{9,10)}$ が背景に記され，今後 は耐性菌のサーベイランス結果と連携して量的・質 的な比較・評価を行う体制を構築し，必要に応じて 対策につなげる仕組みを検討していくといつた方針 が示されている。 また，成果指標にはこうした取り 組みに参加する施設数や検討体制を持つ自治体数を 掲げており，国が自治体をも巻き込みながら対策を 行っていこうとする姿勢が窥える.

このように AMR 対策アクションプランでは，多 面的な角度から，より多くの関係者が協力しなが ら，薬剤耐性に起因する感染症による疾病負荷のな い世界の実現を目指している，また，AMR 対策ア クションプランは 5 年間を 1 つの区切りとしており, 5 年後の 2020 年に向けて毎年成果をまとめながら 目標達成を目指すこととなる。

\section{日本における抗菌薬の使用状況}

筆者はこれまでに日本病院薬剂師会を通じて調査 した日本における注射用抗菌薬の使用動向9)や厚生 労働科学研究で構築した抗菌薬使用動向調査システ ム (Japan Antimicrobial Consumption Surveillance; JACS, https://www.jacs.asia）のなかで販売量に基 づく経口抗菌薬も含めた抗菌薬の使用動向, ${ }^{10)}$ レセ プト情報・特定健診等情報データベース（National Database；NDB）を用いた年齢別における抗菌薬の 使用動向11)を明らかにした。

耐性菌や抗菌薬使用の動向を他国と比較する場 合，医療費や病床数など様々な背景が異なるため, 
Table 1. Goals and Outcome Indexes for AMR Action Plan in Japan

\begin{tabular}{|c|c|c|}
\hline & Fields & Goals \\
\hline 1 & Public Awareness and Education & $\begin{array}{l}\text { Improve Public Awareness and Understanding, and Promote Education and Training of } \\
\text { Professionals }\end{array}$ \\
\hline 2 & Surveillance and Monitoring & $\begin{array}{l}\text { Continuously Monitor Antimicrobial Resistance and Use of Antimicrobials, and } \\
\text { Appropriately Understand the Signs of Change and Spread of Antimicrobial Resistance }\end{array}$ \\
\hline 3 & Infection Prevention and Control & $\begin{array}{l}\text { Prevent the Spread of Antimicrobial-resistant Organisms by Implementing Appropriate } \\
\text { Infection Prevention and Control }\end{array}$ \\
\hline 4 & Appropriate Use of Antimicrobials & $\begin{array}{l}\text { Promote Appropriate Use of Antimicrobials in the Fields of Healthcare, Livestock } \\
\text { Production, and Aquaculture }\end{array}$ \\
\hline 5 & Research and Development & $\begin{array}{l}\text { Promote Research on Antimicrobial Resistance and Foster Research and Development } \\
\text { to Secure the Means to Prevent, Diagnose, and Treat Antimicrobial-resistant Infections }\end{array}$ \\
\hline 6 & International Cooperation & Enhance Global Multidisciplinary Countermeasures against Antimicrobial Resistance \\
\hline
\end{tabular}

HUMAN-RELATED INDEXES

1. Lower the penicillin resistance of Streptococcus pneumoniae to $15 \%$ or less by 2020

2. Lower the methicillin resistance of Staphylococcus aureus to $20 \%$ or less by 2020

3. Lower the fluoroquinolone resistance of Escherichia coli to $25 \%$ or less by 2020

4. Lower the carbapenem (imipenem) resistance of Pseudomonas aeruginosa to $10 \%$ or less by 2020

5. Maintain the carbapenem resistance of Escherichia coli and Klebsiella pneumoniae at $0.2 \%$ or less in 2020

6. Reduce the antimicrobial use per day per 1000 inhabitants by 2020 to two-thirds of the level in 2013

7. Reduce the use of oral cephalosporins, quinolones, and macrolides per day per 1000 inhabitants in 2020 by $50 \%$ of the level in 2013

8. Reduce the use of intravenous antimicrobials per day per 1000 inhabitants in 2020 by $20 \%$ of the level in 2013

単に耐性菌の耐性率や発生率と抗菌薬使用密度 (antimicrobial use density; AUD) などの数值だけ ではなく，日本における医療環境を示すことが重要 である. 2013 年の調査では医療機関を機能別に分 類し，使用量や耐性菌の発生率には施設特性が関与 すること，施設特性によって人的資源が異なり，十 分な係わりができない状況が懸念される一方で, 「届出制」など，抗菌薬管理プログラムの有無につ いてはいずれにおいても差がなく，質的な評価が必 要であることを報告した。

耐性菌の選択には注射薬だけでなく経口薬も含め たすべての抗菌薬における選択圧を評価しなければ ならない。 そこで，2016 年の調査では販売量に基 づき，すべての抗菌薬の使用状況を明らかにした (Fig. 1). 2013 年の日本における抗菌薬全体の総使 用量は 15.8 DID (defined daily doses; DDDs/1000 inhabitants/d) であり，2009 年と比較して経口・ 注射薬ともに増加傾向であった。しかしながら, EU 諸国 ${ }^{12)}$ （21.6 DID, 2014 年），韓国 ${ }^{13) （ 21.7}$ DID, 2012 年), アメリカ14）（24.9 DID, 2014 年） と比較してもそれほど大きな違いは認めなかった が，使用量の約 9 割を経口薬が占めており，使用比
率では，欧州と比べてペニシリン系が少なく，特に 第 3 世代セファロスポリン系，マクロライド系，キ ノロン系が高いことが明らかになった（Fig. 2)。

NDB を用いた調査では，販売量データと異な り，使用した患者背景で分類できるため，年齢を 5 歳毎に分類して使用状況を明らかにした（Fig. 3). 経口抗菌薬は小児や高齢者で多く使用され，注射用 抗菌薬は高齢になる程使用されていた。また，今回 示した值は医薬品の主な適応症に対する成人の 1 日 仮想平均維持量（DDD）で補正しているため，実 際の小児や高齢者に対して過少評価をしている可能 性があり，実際にはさらに使用されていることが推 察された。 さらに，小児や高齢者において全体の使 用割合で多かった第 3 世代セファロスポリン系薬,

マクロライド系薬，キノロン系薬の使用頻度も多い ことも明らかとなった。

抗菌薬適正使用支援 (antimicrobial stewardship; AS）における薬剤師の役割

AS とは，主治医が抗菌薬を使用する際，個々の 患者に対して最大限の治療効果を導くと同時に，有 害事象をできるだけ最小限に留め，いち早く感染症 治療が完了できる (最適化する)ようにする目的で, 
(A) Oral antibacterial drug DDDs/1,000 inhabitants/day

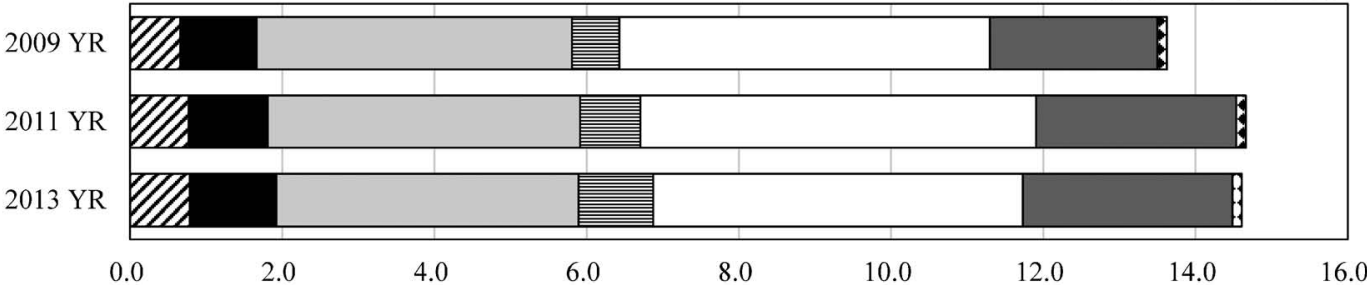

(B) Parenteral antibacterial drug

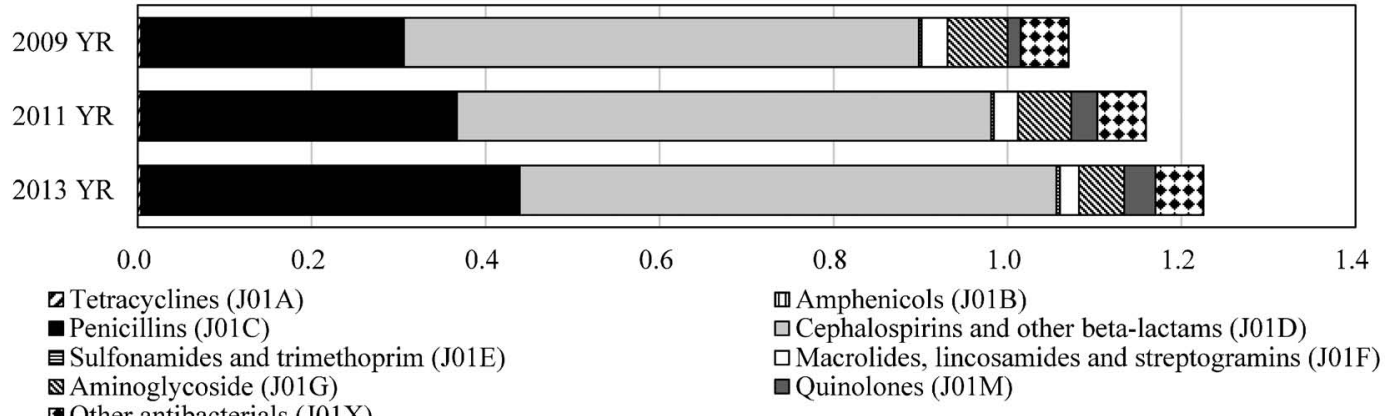

Fig. 1. Consumption of Antibacterial Drugs Based on Sales Data at the ATC Group Level 3 in Japan during 2009-2013 Data are expressed as DDD per 1000 inhabitants and per day.

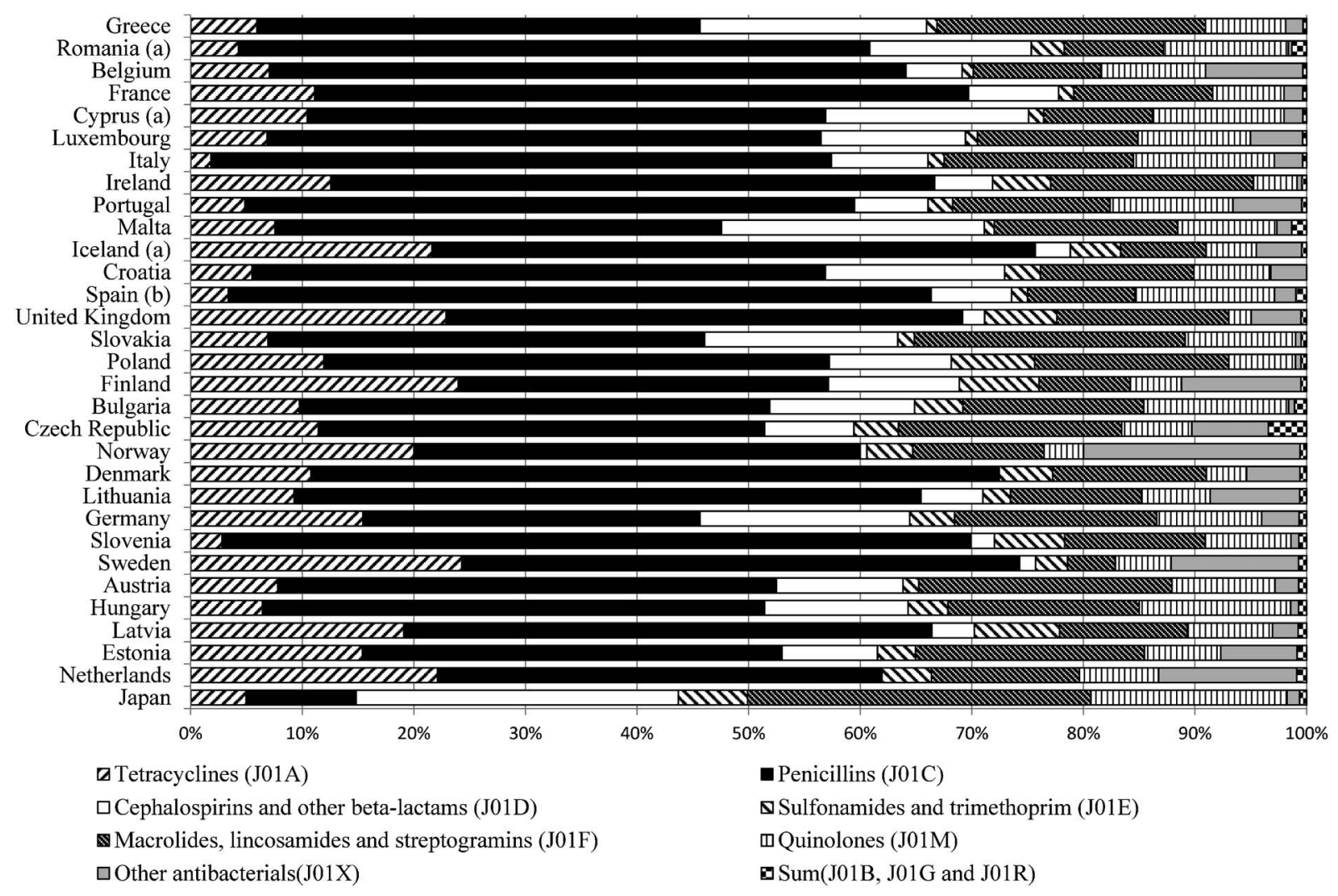

Fig. 2. Comparison of the Proportion for Antimicrobial Consumption between Japan and European Countries in 2013 
(A) Oral antibacterial drug

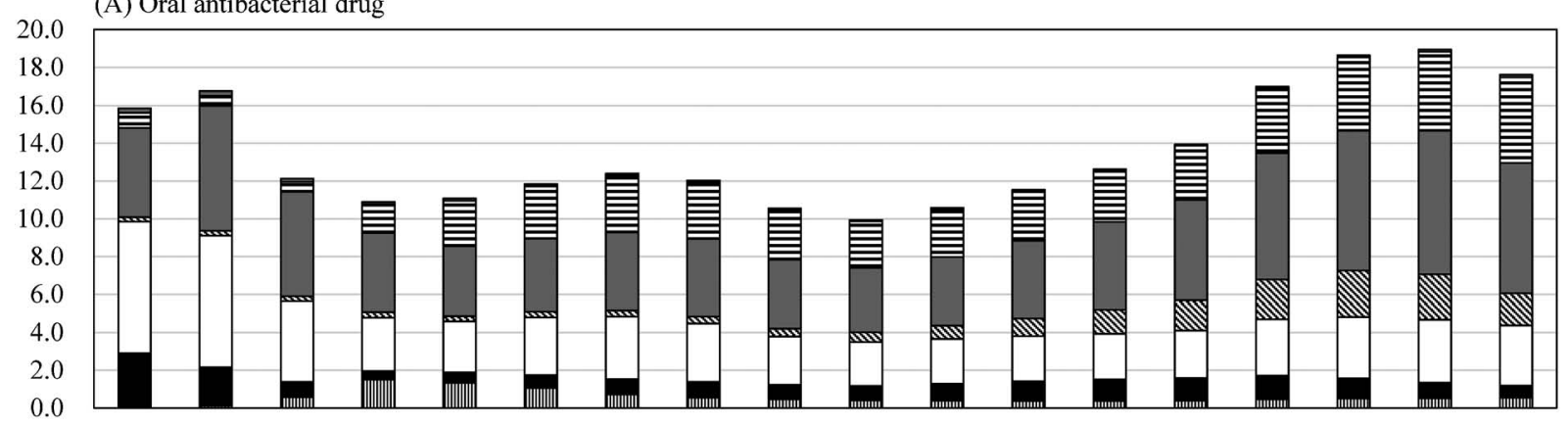

0-4y 5-9y $10-14$ y $15-19 y$ 20-24y 25-29y 30-34y 35-39y 40-44y 45-49y 50-54y 55-59y 60-64y 65-59y 70-74y 75-79y 80-84y 85 y-

(B) Parenteral antibacterial drug

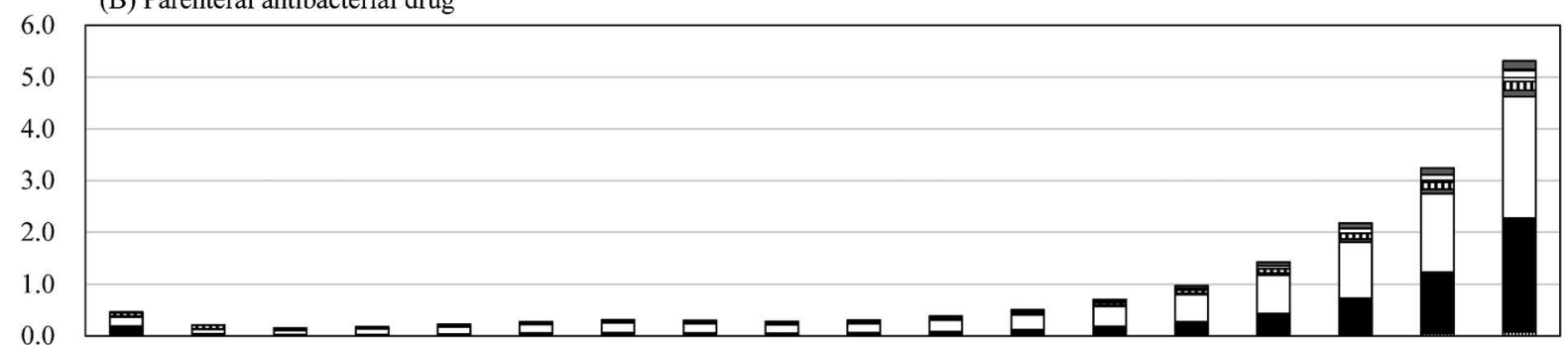

$0-4$ y $\quad 5-9$ y $10-14$ y $15-19$ y 20-24y 25-29y 30-34y 35-39y 40-44y 45-49y 50-54y 55-59y 60-64y 65-59y 70-74y $75-79$ y $80-84$ y 85 y-

m Tetracyclines (J01A)

- Penicillins (J01C)

$\$$ Sulfonamides and trimethoprim (J01E)

m Aminoglycoside (J01G)

口Other antibacterials (J01X)
Amphenicols (J01B)

$\square$ Cephalospirins and other beta-lactams (J01D)

$\square$ Macrolides, lincosamides and streptogramins (J01F)

日Quinolones (J01M)

Fig. 3. Consumption of Antibacterial Drug Based on Claims Data at the ATC Group Level 3 in Japan, 2013 Data are expressed as DDD per 1000 inhabitants and per day.

感染症専門の医師や薬剤師，臨床検査技師，看護師 が主治医の支援を行うことである. ${ }^{15)}$ 抗菌薬の安易 （不必要）な使用や不適切な使用は耐性菌を発生あ るいは蔓延させる原因となるため, AS を推進する ことは耐性菌の出現を防ぐ，あるいは遅らせること ができ，医療コストの削減にもつながることが様々 な国から報告されている.16) すなわち，AS は感染 症診療における耐性菌抑制と予後向上を両立させる ための中心的役割を担っており, 平成 30 年度の診 療報酬改定においても，医療機関に AS を行うため のチーム（抗菌薬適正使用支援チーム, antimicrobial stewardship team; AST) やASを行うた めの指針（抗菌薬適正使用支援プログラム，antimicrobial stewardship program; ASP）を整備し, 活動することに対して加算が新設された.

わが国における AS の基本戦略には，(1)介入 (interventions), (2)抗菌薬使用の最適化 (optimization), (3)微生物検查診断の利用 (microbiology and laboratory diagnostics), (4)AS の評価測定 (measurement），(5)特殊集団の選択と AS の集中（special population), (6)教育・啓発 (education) が挙げら れている.17) すなわち，抗菌薬の適正使用を支援す る対象（患者）をどのように集め，監視し，どのよ うなタイミングで，どのような内容を，どの程度関 与するかについて決定しなければならない。各医療 機関では感染症診療や感染制御に関して専門資格を 有する人員が不足していることが縣念されるため, 施設状況に応じて継続的に取り組める内容を設定す る必要がある.

これまで, 特定の抗菌薬使用時に届出書を起点と した対象の把握が行われてきたが，施設内での形骸 化や既に治療が開始されてしまっているといった問 題がある. また, 従来の紙べースの届出制による把 握では即時対応に限界があるため，できれば電子力 ルテや感染管理ソフトなど情報技術（IT）の導入 による作業の効率化や省力化が求められてい る. ${ }^{18,19)}$ 最近では, 血液培養陽性など感染の徵候を モニタリング開始のトリガーとすることや, 20) 集中 治療室の患者や発熱性好中球減少症など特定の患者 や疾患群をモニタリング対象とすることも効果的と 
Table 2. Evaluation Indexes for Various Interventions in Antibiotic Therapy

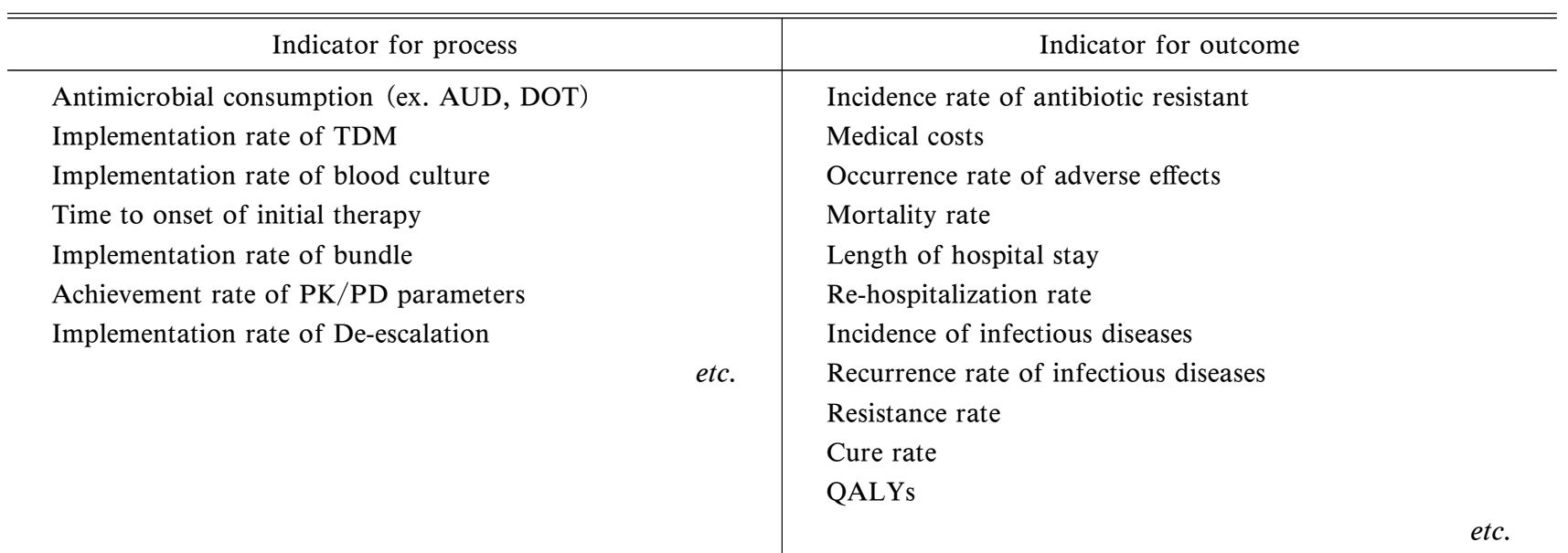

AUD, antimicrobial use density; DOT, days of therapy; TDM, therapeutic drug monitoring; PK/PD, pharmacokinetics/pharmacodynamics; QALYs, qualityadjusted life years. Process is not an absolute criterion as it changes with outcome. It is desirable to use objective and reproducible indicators.

されており, 17)こうした介入に対して薬剤師には中 心的な役割を担うことが求められている.

抗菌薬適正使用を推進するためには, AST によ る適切な介入が求められる. 有効な介入手段とし て, 欧米では（i）感染症治療の早期モニタリング とフィードバック (prospective audit and feedback) や（ii）抗菌薬使用の事前承認 (preauthorization) の 2 項目が推奨されており, ${ }^{15,21)}$ ASP では欠かすこ とのできない戦略としてわが国でもすべての施設で 検討すべきである。一方，わが国では，欧米のよう に特定の抗菌薬を使用する前に事前の許可や承認を 必要とする運用はマンパワーなどの問題から現実的 ではない，そのため，わが国では，感染症治療の早 期モニタリングとフィードバックの実践が現実的で ある。すなわち，前述した各施設で決定した把握方 法に基づき抽出された対象に対して，治療の早期か ら後述する内容についてモニタリングを開始し，経 過をフォローアップしながら，必要に応じて主治医 にアドバイスを行う方法である．投与中の継続的な 支援には，マンパワーを要するため，AST を担当 する薬剤師を中心として病棟に配置する薬剤師と連 携することが重要である.

AMR 対策アクションプランでも掲げられている が，教育・啓発活動も抗菌薬適正使用の推進に欠か すことのできない要素である. ${ }^{15,21)} \mathrm{AS}$ の教育は, 講義のような受動教育より能動教育，すなわち ASP の実践過程での個別教育が望ましく，AS を行 う上で主治医に行われる AST からのフィードバッ
クが学びの機会となる. ${ }^{22)}$ フィードバックは，批判 ではなく改善することを目的として行われるべきで ある。また，主治医が早期に必要な微生物検查を オーダーし, 適切な患者検体（血液培養 2 セット, 中間尿，良質の喀痰等）が採取できるような教育・ 啓発活動も AST の重要な役割である。さらに，医 療従事者だけでなく学生や患者など対象範囲を拡大 するなど，AS の効果を高める工夫が今後，望まれ ている.

最後に ASP の効果は自己評価し，ASP の改善に 役立てなければならない。自己評価には AS のプロ セスとアウトカムの両者を検証する (Table 2)。プ ロセスの評価指標には，抗菌薬の使用状況を示す AUD や治療日数（days of therapy; DOT）や therapeutic drug monitoring (TDM) 実施率など介入内 容を直接反映する指標が用いられる。これらの指標 を正しく算出, 評価できる職種は薬剤師が最も適し ており，医療機関に勤務する薬剂師だけでなく，保 険薬局の薬剤師においても今後中心的な役割を担う ことが求められる.

一方，アウトカム指標には臨床的改善を反映する 指標（死亡率，入院期間，治癒率，再発率，治療費 など）や，微生物学的な改善を反映する指標（耐性 菌の検出数や発生率など）が用いられる，各施設で 決定した ASP を実践し，プロセスやアウトカムが 改善したか否かを評価した後，管理者へフィード バックすることで更なる人員の補充なども検討可能 となる。その後，ASP をさらに充実したものへ改 
訂し，より質の高い AS を実践していくことが重要 である。

\section{最後に}

今回の AMR 対策アクションプランでは，筆者が 日本病院薬剤師会を通じて調査した日本における抗 菌薬使用動向の調査結果9) や厚生労働科学研究で実 施した調査結果10)が引用されている。 また，感染対 策チームにおいて適正使用に係わる薬剤師23) やクリ ニックでグラム染色を実施し，適正使用を支援する 薬剂師 ${ }^{24)}$ による医療費の削減効果も引用されてい る.これまで，わが国では抗菌薬使用動向を把握す る仕組みやチーム医療における薬剤師の必要性が評 価され難い環境であった。しかしながら，様々な医 療情報の電子化が進み，膨大なデー夕を利用し易い 環境が整いつつある. AMR 対策アクションプラン やChoosing Wisely といった活動が注目され，更な る医薬品の適正使用が求められる今, 感染症診療や 感染対策に係わる薬剤師だけでなく，すべての薬剤 師が一丸となり，貢献した結果を示していくことが 求められている.

利益相反 開示すべき利益相反はない.

\section{REFERENCES}

1) Brody H., N. Engl. J. Med., 362, 283-285 (2010).

2) Tokuda Y., "Japanese Consortium for General Medicine Teachers Vol. 5, Choosing wisely in Japan: Less is More," Ojima Igaku Kyouiku Kenkyujo, Tokyo, 2014.

3) Koizumi S., Nihon Naika Gakkai Zasshi, 105, 2441-2449 (2016).

4) Terada T., Iyaku Journal, 52, 2223-2225 (2016).

5) Shane R., Abramowitz P. W., Am. J. Health Syst. Pharm., 72, 1529-1530 (2015).

6) Giske C. G., Monnet D. L., Cars O., Carmeli Y., Antimicrob. Agents Chemother., 52, 813821 (2008).

7) Ministry of Health, Labour and Welfare. "National Action Plan on Antimicrobial Resistance (AMR).”: 〈https://www.mhlw. go.jp / file / 06-Seisakujouhou-10900000-Ken koukyoku/0000138942.pdf $\rangle$, cited 24 July, 2018.
8) The Japanese Association for Infectious Diseases: 〈http://www.kansensho.or.jp/guide lines/pdf/1405_teigen2.pdf $\rangle$, cited 24 July, 2018.

9) Muraki Y., Kitamura M., Maeda Y., Kitahara T., Mori T., Ikeue H., Tsugita M., Tadano K., Takada K., Akamatsu T., Yamada T., Shiraishi T., Okuda M., Infection, 41, 415423 (2013).

10) Muraki Y., Yagi T., Tsuji Y., Nishimura N., Tanabe M., Niwa T., Watanabe T., Fujimoto S., Takayama K., Murakami N., Okuda M., J. Glob. Antimicrob. Resist., 7, 19-23 (2016).

11) Yamasaki D., Tanabe M., Muraki Y., Kato G., Ohmagari N., Yagi T., Infection, 46, 207214 (2018).

12) European Centre for Disease Prevention and Control. "Summary of the latest data on antibiotic consumption in the European Union: 2015. ESAC-Net surveillance data."”:〈http:// ecdc.europa.eu / en / eaad / antibiotics-news / Documents / antimicrobial-consumption-ESACNet-summary-2015.pdf $\rangle$, cited 24 July, 2018.

13) Yoon Y. K., Park G. C., An H., Chun B. C., Sohn J. W., Kim M. J., Medicine (Baltimore), 94, e2100 (2015).

14) Goossens H., Ferech M., Coenen S., Stephens P., Clin. Infect. Dis., 44, 1091-1095 (2007).

15) Dellit T. H., Owens R. C., McGowan J. E. Jr., Gerding D. N., Weinstein R. A., Burke J. P., Huskins W. C., Paterson D. L., Fishman N. O., Carpenter C. F., Brennan P. J., Billeter M., Hooton T. M., Clin. Infect. Dis., 44, 159177 (2007).

16) Cao H., Phe K., Laine G. A., Russo H. R., Putney K. S., Tam V. H., J. Glob. Antimicrob. Resist., 6, 75-77 (2016).

17) Niki Y., Jpn. J. Chemother., 65, 650-687 (2017).

18) Muraki Y., Tanabe M., Nakamura A., Matsushima Y., Seno M., Fukuda M., Okuda M., Jpn. J. Pharm. Health Care Sci., 36, 316-322 (2010).

19) Yamada T., Umetsu N., Ohtaki K., Tsunakawa T., Satoh M., Koshiro K., Ono T., Suno M., Iida S., Yamashita T., Awaya T., Tasaki Y., Matubara K., Jpn. J. Pharm. Health Care Sci., 34, 419-425 (2008).

20) Maeda M., Takuma T., Yoshikawa M., Naito 
Y., Tsuchiya A., Oto Y., Minemura A., Ugajin K., Shoji H., Ishino K., Niki Y., Jpn. J. Chemother., 63, 350-356 (2015) .

21) Barlam T. F., Cosgrove S. E., Abbo L. M., MacDougall C., Schuetz A. N., Septimus E. J., Srinivasan A., Dellit T. H., Falck-Ytter Y. T., Fishman N. O., Hamilton C. W., Jenkins T. C., Lipsett P. A., Malani P. N., May L. S., Moran G. J., Neuhauser M. M., Newland J. G., Ohl C. A., Samore M. H., Seo S. K., Trivedi K. K., Clin. Infect. Dis., 62, e51-e77
(2016) .

22) Chung G. W., Wu J. E., Yeo C. L., Chan D., Hsu L. Y., Virulence, 4, 151-157 (2013).

23) Niwa T., Shinoda Y., Suzuki A., Ohmori T., Yasuda M., Ohta H., Fukao A., Kitaichi K., Matsuura K., Sugiyama T., Murakami N., Itoh Y., Int. J. Clin. Pract., 66, 999-1008 (2012).

24) Maeda M., Maeda T., Matsumoto K., Morita K., An Official Journal of the Japan Primary Care Association, 38, 335-339 (2015). 